\title{
Nationally Representative Plot Network Reveals Contrasting Drivers of Net Biomass Change in Secondary and Old-Growth Forests
}

\author{
Robert J. Holdaway, ${ }^{1 *}$ Tomás A. Easdale,${ }^{1}$ Fiona E. Carswell,${ }^{1}$ \\ Sarah J. Richardson, ${ }^{1}$ Duane A. Peltzer, ${ }^{1}$ Norman W. H. Mason, ${ }^{2}$ \\ Andrea M. Brandon, ${ }^{3}$ and David A. Coomes ${ }^{4}$
}

\footnotetext{
${ }^{1}$ Landcare Research, PO Box 69040, Lincoln 7640, New Zealand; ${ }^{2}$ Landcare Research, Private Bag 3127, Hamilton 3240, New Zealand; ${ }^{3}$ Ministry for the Environment, 23 Kate Sheppard Place, Wellington 11040, New Zealand; ${ }^{4}$ Forest Ecology and Conservation Group, Department of Plant Sciences, University of Cambridge, Downing Street, Cambridge CB2 3EA, UK
}

\begin{abstract}
Uncertainty about the mechanisms driving biomass change at broad spatial scales limits our ability to predict the response of forest biomass storage to global change. Here we use a spatially representative network of 874 forest plots in New Zealand to examine whether commonly hypothesised drivers of forest biomass and biomass change (diversity, disturbance, nutrients and climate) differ between old-growth and secondary forests at a national scale. We calculate biomass stocks and net biomass change for live above-ground biomass, belowground biomass, deadwood and litter pools. We combine these data with plot-level information on forest type, tree diversity, plant functional traits,
\end{abstract}

Received 8 November 2015; accepted 13 September 2016; published online 28 November 2016

Electronic supplementary material: The online version of this article (doi:10.1007/s10021-016-0084-x) contains supplementary material, which is available to authorized users.

Author contributions A.B. led the data collection programme. R.J.H., F.E.C., D.A.C., D.A.P. and S.J.R. conceived the study. S.J.R. and D.A.P. provided the trait data. R.J.H. led and T.A.E. and N.W.M. assisted with the analysis. R.J.H. wrote the paper with substantial contributions from all the co-authors.

*Corresponding author; e-mail: holdawayr@landcareresearch.co.nz climate and disturbance history, and use structural equation models to identify the major drivers of biomass change. Over the period 2002-2014, secondary forest biomass increased by 2.78 (1.683.89) $\mathrm{Mg} \mathrm{ha}^{-1} \mathrm{y}^{-1}$, whereas no significant change was detected in old-growth forests $(+0.28 ;-0.72$ to $\left.1.29 \mathrm{Mg} \mathrm{ha}^{-1} \mathrm{y}^{-1}\right)$. The drivers of biomass and biomass change differed between secondary and old-growth forests. Plot-level biomass change of old-growth forest was driven by recent disturbance (large tree mortality within the last decade), whereas biomass change of secondary forest was determined by current biomass and past anthropogenic disturbance. Climate indirectly affected biomass change through its relationship with past anthropogenic disturbance. Our results highlight the importance of disturbance and disturbance history in determining broad-scale patterns of forest biomass change and suggest that explicitly modelling processes driving biomass change within secondary and old-growth forests is essential for predicting future changes in global forest biomass.

Key words: carbon; disturbance; diversity; ecosystem function; New Zealand; species composition; temperate forest; UNFCCC. 


\section{INTRODUCTION}

Globally, forests provide a significant reservoir of non-atmospheric carbon, equivalent to $861 \pm 66$ $\mathrm{Pg}$, and this reservoir is thought to be growing at a rate of $2.4 \pm 0.4$ Pg per year (Pan and others 2011). However, the ongoing capacity of forests to act as a net carbon sink depends on complex and often interacting forces of global change, including natural and anthropogenic disturbance (Kurz and others 2008; Reichstein and others 2013; Berenguer and others 2014), climate change (Phillips and others 2009; Reichstein and others 2013) and changes in community composition (Coomes and others 2014). Shifts in biomass stock (here defined as live above-ground biomass, below-ground biomass, deadwood and litter pools) over time reflect an imbalance between biomass gains through growth and recruitment, and losses due to mortality, harvesting, decomposition, respiration and combustion. Disturbance, environmental conditions and forest species composition and diversity affect all these processes, but the relative importance and magnitude of these effects is unresolved (for example, Fisher and others 2008; Coomes and others 2012, 2014; Fernández-Martínez and others 2014; Durán and others 2015; Poorter and others 2015).

The multiple drivers of forest biomass change can interact in complex ways across multiple spatial scales. This introduces additional sources of uncertainty in future forecasting of biomass storage and can obscure the importance of these drivers at national or global scales (Fisher and others 2008; Chambers and others 2009; Erb and others 2013). Drivers that are important at local scales may become obscured or unimportant at larger spatial scales relevant to country-level UNFCCC reporting and international climate liabilities, or for assessing the relative impacts of drivers of forest change at a global scale. For example, climate or nutrient availability may drive biomass change at local scales (for example, within undisturbed old-growth forest); however, at larger spatial scales the relationship between nutrient availability and growth may become overshadowed by changing forest composition and structure due to past disturbance (Erb and others 2013; Canham 2014). Efforts to disentangle the drivers of biomass change consider only a limited number of drivers in isolation (for example, Fisher and others 2008; Chisholm and others 2013; Coomes and others 2014; Fernández-Martínez and others 2014) or are strongly reliant on extrapolations from few well-characterised systems (for example, Chambers and others 2009; Erb and others 2013). In addition, most of this literature has focussed on understanding biomass, rather than net biomass change, often assuming that biomass and net biomass change are positively correlated (for example, Stegen and others 2011; Chisholm and others 2013; Poorter and others 2015).

These efforts are hindered by uncertainty around the relative importance and landscape-level contribution of potential drivers (Erb and others 2013; Fernandez-Martinez and others 2014; Michaletz and others 2014). Furthermore, interactions among drivers may lead to indirect effects that are difficult to detect at local or regional scales or when the potential drivers of NEP are considered in isolation (Fisher and others 2008; Chambers and others 2009; Erb and others 2013). Although the importance of old-growth forests for biomass storage has received considerable attention (Luyssaert and others 2008; Pan and others 2011), secondary forests have been relatively overlooked because they contain lower biomass stocks. This is surprising because these forests are typically accumulating biomass through the process of stand development and are a critical component of landscape-scale biomass change. Biomass storage in old-growth and secondary forests is likely to respond differently to environmental drivers, because of their contrasting age class structures, diversity profiles and species composition, and age-specific responses of trees to climate and resource availability. Data from secondary forests are scarce compared to old-growth forests, and seldom have both old-growth and secondary forests been analysed coincidentally (Berenguer and others 2014). Such comparisons are needed to determine how old and secondary forests differ in their responses to multiple drivers of forest biomass change.

New Zealand's forests provide an excellent case study for simultaneously assessing the relative drivers of biomass change in both old-growth and secondary forests. This is because New Zealand's relatively recent settlement history (c. $1280 \mathrm{AD}$; Wilmshurst and others 2008) has generated a clear initiation of anthropogenic disturbances (Perry and others 2012), which, coupled with a range of natural disturbances from storms and tectonic activity, has created a mosaic of both old-growth and secondary forests (McGlone 1989). This contrasts with many Northern Hemisphere forests that have had millennia of human influence (for example, eastern North America, Canham 2014; western Europe, Kalis and others 2003), making the identification of 
old-growth forest difficult or intractable. In addition, New Zealand forest communities have been quantitatively classified (Wiser and others 2011), and a range of climate and trait data (for example, rainfall, leaf nitrogen content) are available at a national scale, enabling simultaneous assessment of multiple ecosystem drivers.

Here we present new biomass stock and net biomass change data from a nationally representative network of 874 temperate forest plots. Representative plot networks provide ideal datasets to resolve the landscape-scale drivers of forest change because the sampling design reduces the risk of introducing sampling bias (Fisher and others 2008; Salk and others 2013). However, such data are scarce, especially from southern temperate forests. Often, forest biomass estimates rely on localised plot networks (for example, Lewis and others 2009), or networks that omit key pools, such as deadwood (for example, Coomes and others 2014). Our plot network was designed specifically for monitoring and reporting changes in New Zealand's biomass pools for UNFCCC reporting (Coomes and others 2002; Ministry for the Environment 2014), includes measured deadwood pools (Richardson and others 2009) and encompasses a range of old-growth and secondary forests. We combine these data with extensive plotlevel information on forest type, tree diversity, plant traits, climate and disturbance history, and apply integrated multivariate analyses to identify the major drivers of forest biomass and biomass change at a national scale. We aim to resolve two questions: First, what were the relative contributions of secondary and old-growth forests to national-scale biomass and biomass change over the period 20022014? Second, and more generally, do the commonly hypothesised drivers of forest biomass and biomass change differ between old-growth and secondary forests at a national scale? By resolving these questions, we provide general insights into the broad-scale determinants of forest biomass change.

\section{MeTHODS}

\section{Study Area}

Our study area encompasses 7.8 million ha of natural forest located on the central islands of New Zealand (that is, excluding Chatham, Kermadec and sub-Antarctic Islands, Figure 1). Natural forests span a broad latitudinal gradient ranging from subtropical $\left(34^{\circ} \mathrm{S}\right)$ to cool temperate $\left(47^{\circ} \mathrm{S}\right)$ and cover a range of landforms from sea level to tree line at approximately $1250 \mathrm{~m}$ a.s.l. As a global biodiversity hotspot, New Zealand is rich in endemic species (Myers and others 2000), but its forests also possess phylogenetic and ecological similarities to other less studied southern temperate rainforests in South America and Australia, as well as tropical mountain forests of the South Pacific, Australasia and South America (Wardle 1973).

\section{Representative Plot Network}

Plot data were collected as part of New Zealand's Land Use and Carbon Analysis System (LUCAS). LUCAS combines wall-to-wall, satellite-based mapping with field inventories to underpin New Zealand's ability to meet international reporting requirements under the UNFCCC and the Kyoto Protocol (Ministry for the Environment 2014). A major component of LUCAS is a national grid of permanent plots that systematically sample existing (pre-1990) natural forest. This plot network was specifically designed to monitor national biomass stocks and biomass stock change (Coomes and others 2002) and is based on 0.04-ha plots $(20 \times 20 \mathrm{~m}$ land surface area) located on an 8-km grid across New Zealand. The initial point (that is, the origin) was selected at random, and then the rest of the grid was derived in relation to that point, resulting in a set of evenly spaced randomly located plots. The 0.04 ha plot size was chosen to integrate with existing field protocols and vegetation survey data across New Zealand (Wiser and others 2001). An additional 20-m-radius plot was piloted as per the recommendations of Coomes and others (2002) in an attempt to reduce the variance associated with large trees, but this method was found to be unreliable for New Zealand's dense natural forest and steep, highly dissected terrain. Spatially representative permanent plots with repeated measurements offer unbiased information at national scales, with comparatively small plot size being more than compensated for by the increase in geographic coverage (Salk and others 2013). We defined our sample universe as the pre-1990 'Natural Forest' class of the current 2008 LUCAS Land Use Map (LUM, sourced from the New Zealand Ministry for the Environment, August 2014). This sampling universe has 1215 potential plot locations based on the LUCAS $8-\mathrm{km}$ grid and represents approximately 7.84 million ha of forest. A total of $1040(86 \%)$ of these grid locations had permanent sampling plots established during 2002-2007. Plots were not established where access permission was denied or where safety issues prevented plot establishment. Of the 1040 plots established, 874 $(84 \%)$ randomly selected plots were re-measured during 2009-2014. Mean measurement interval 


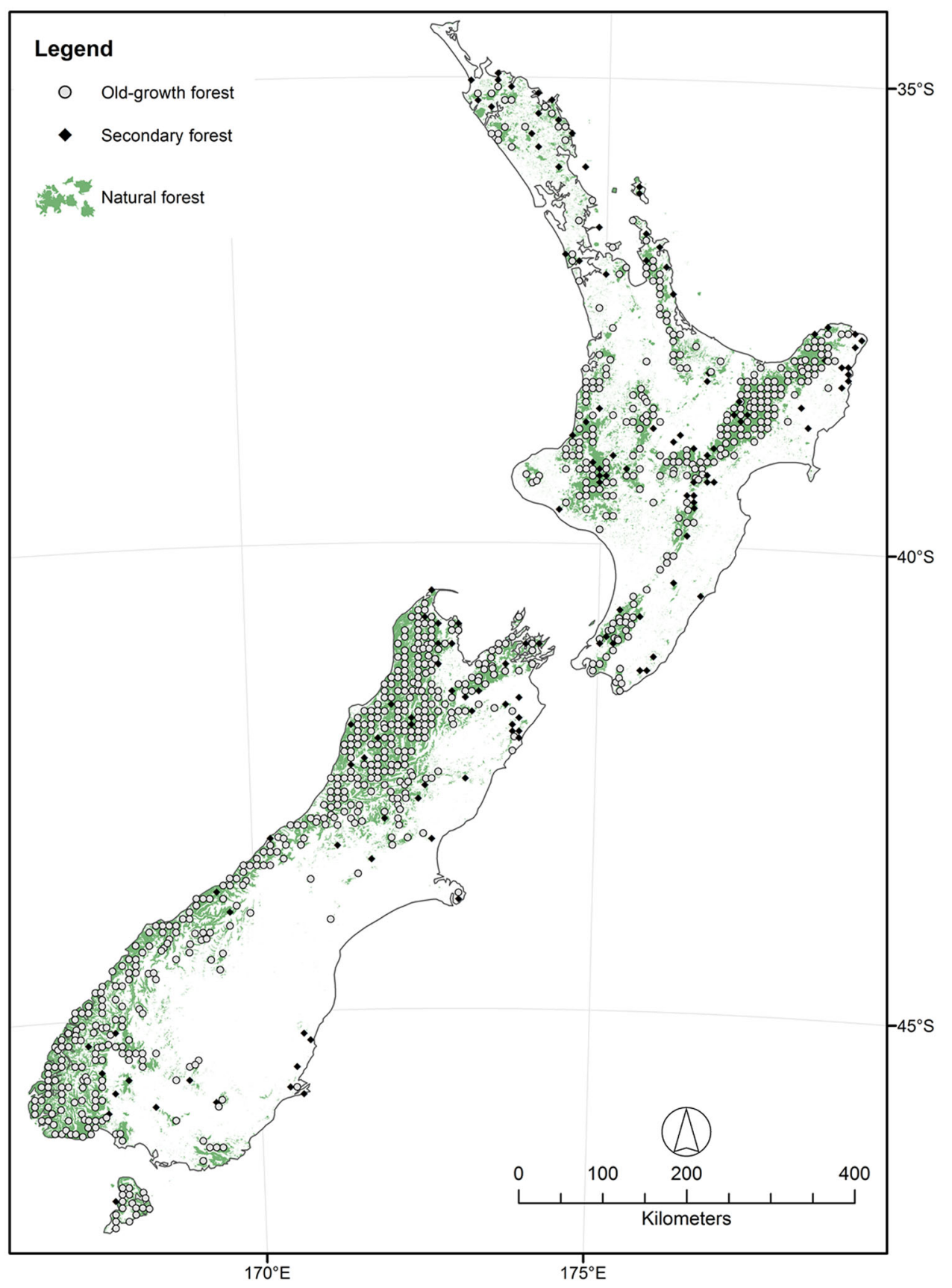

Figure 1. Locations of 874 plots forming a representative sample of New Zealand's pre-1990 natural forest.

was 7.7 years (minimum 6, maximum 9.3). To allow direct comparison of biomass and net biomass change measurements, we restricted our analysis to the 874 re-measured plots. These plots have nationwide coverage and provide a representative random sample of New Zealand's pre-1990 natural forest (Figure 1). This sampling design assumes that each plot represents $1 / 874$ of the total forest area (c. 9000 ha per plot), allowing us to estimate total national carbon stock and stock change simply by multiplying the sample mean by the total forest area.

\section{Plot Measurements}

Within each plot, all live stems at least $2.5 \mathrm{~cm}$ diameter at $1.35 \mathrm{~m}$ above ground (diameter at breast height, $D$ ) were tagged, identified to species and measured. Diameters of standing dead stems $(\geq 10 \mathrm{~cm} D)$ were measured and scored for degree of decay using an ordinal decay class (Coomes and others 2002). Height was measured on a subset of live stems and all standing dead stems. For plots consisting primarily of shrubs (that is, plants $<2.5 \mathrm{~cm} \mathrm{D}$ ), measurements of crown 
volume were made inside the plot and representative samples were harvested outside the plot. Dimensions of fallen dead material $(\geq 10 \mathrm{~cm} D)$ and standing dead stems were measured and each piece scored using the same ordinal decay classes applied to standing dead stems. Litter was measured during the 2002-2007 campaign only. Field methods are described fully by Payton and others (2004) and the Ministry for the Environment (2012). Since 2009, an independent audit of $10 \%$ of the plots was conducted each year to ensure high data quality standards.

\section{Data Preparation and Error Checking}

Data errors may create bias (compromising accuracy) or lower precision of the resulting biomass estimates (Muller-Landau and others 2014). We therefore implemented a comprehensive range of data-checking procedures to ensure that our data met minimum data quality standards (Wiser and others 2001). Error checking included standard checks that can be performed on batched data, such as plot attributes, species name codes, ranges of values and consistency of individual stem tag numbers across measurements, through to manual checking of raw data files (handwritten data sheets filled in by the fieldworker while on a plot). For repeatability and transparency, the original data (that is, the LUCAS database, held by the New Zealand Ministry for the Environment) were left intact, and all data checks and corrections were coded using the R platform (R Development Core Team 2013). Excessive pruning, cleaning or correction of raw data can introduce bias that may have a greater effect on the accuracy of the results than the original measurement errors (MullerLandau and others 2014). We therefore took a precautionary approach, correcting only extreme data outliers that could be clearly traced to obvious field or data-entry mistakes. The effects of remaining measurement error in the data were quantitatively incorporated into the biomass calculations using Monte Carlo simulations, drawing from measurement error distributions based on blind repeat measurements of forest plots (Holdaway and others 2014).

\section{Biomass Calculations}

Total biomass stocks for both time periods were calculated as the sum of four biomass pools: live above-ground biomass (AGB), live below-ground biomass (BGB), aboveground deadwood (DW) and litter (LITTER). Two separate sets of calculations were performed for the above-ground biomass pool: one for trees and tree ferns at least $2.5 \mathrm{~cm} \mathrm{D}$ $\left(\mathrm{AGB}_{\text {tree }}\right)$ and one for shrubs $\left(\mathrm{AGB}_{\text {shrub }}\right)$. This reflects the differences in methodology between treedominated versus shrub-dominated plots (Payton and others 2004). Biomass content of individual live trees $\left(\mathrm{AGB}_{\text {tree }}\right)$ was calculated using an allometric function for New Zealand trees that incorporates stem volume derived from diameter $(D)$ and height $(H)$, and species-specific wood density (Beets and others 2012). Two independent tree height measurements (one at each measurement period) were not available for $83.8 \%$ of the live stems. For these stems, species-specific allometric equations based on a database containing over 64,000 records for 234 species were used to calculate height (Holdaway and others 2014). Wood density values were taken from a database containing records for a total of 113 species (data available online at the Landcare Research Datastore; http://dx.doi.org/10.7931/J2X34VDD). For species without species-specific wood density or tree height models, the corresponding genus-level average was used and where that was unavailable, the growth-form average was used (Flores and Coomes 2011; Coomes and others 2014). For the $48 \%$ of tree ferns that did not have measured heights, we used the average height for that species, either within the plot or across all plots, because tree ferns do not exhibit a reliable relationship between $D$ and $H$. Aboveground shrub biomass $\left(\mathrm{AGB}_{\text {shrub }}\right)$ was calculated from the measurements of orthogonal widths and height of individual shrub crowns or from the measurements of shrub cover and height within each subplot following Coomes and others (2002). Shrub volume was converted into biomass using crown density allometries (that is, amount of biomass per unit of shrub volume) that were fitted using data from harvests of discrete or continuous shrubs near each plot (T.A.E. unpublished data). Total live above-ground biomass (AGB) was obtained for each plot by summing the biomass of all individual stems and shrubs within the plot and dividing by the slope-corrected (horizontal) plot area.

For standing deadwood ( $>1.3 \mathrm{~m}$ tall, $\geq 10 \mathrm{~cm} D)$, biomass was estimated using volume and taper equations developed for New Zealand trees (Beets and others 2012). The total biomass remaining for standing dead stems was adjusted for decay class using either a species-specific decay sequence where available ( $N=4$ species) or an average decay sequence of 100, 82, 66 and $47 \%$ for decay classes $0,1,2$ and 3, respectively (Coomes and others 2002). For fallen CWD, the volume $\left(\mathrm{m}^{3}\right)$ of each individual piece was estimated using the formula 
for a truncated cone. The biomass of each piece of fallen CWD was calculated as the product of wood volume, wood density and decay class modifier (as described above for standing dead stems). Total biomass in standing and fallen deadwood for each plot (i) was obtained by summing the individual pieces within each plot and dividing by slope-corrected plot area.

Belowground biomass was estimated as $25 \%$ of the above-ground biomass contained in live trees, shrubs and standing deadwood (Phillips and Watson 1994; Coomes and others 2002). Although the ratio of $A G B$ to $B G B$ will vary among sites and species, the value of $25 \%$ represents our best estimate of the national average given current information. We chose to include BGB in our calculations as it represents an important, albeit poorly estimated biomass pool. Including BGB as a constant fraction of AGB affects our total biomass and biomass change estimates but not our analysis of the drivers of net biomass change. Biomass contained in the LITTER pool included fine woody debris (FWD), litter and the fermenting and humus layer (FHO). Data for the litter pool were collected for only $26 \%$ of the plots from the 2002-2007 measurement. We modelled LITTER biomass for the remaining plots as a log-log function of plotlevel DW and AGB. As litter pools for 2009-2014 were not measured, our analysis of net change does not include this biomass pool. Biomass change was calculated for paired plots as the biomass of each pool (except litter) during 2009-2014 minus the biomass for that pool during 2002-2007. These values were converted into annual rates by dividing by the plot-specific measurement interval.

\section{Uncertainty Propagation}

Uncertainty in the biomass and biomass change estimates can arise from process uncertainty (that is, the natural variability among plots), measurement error and uncertainty in the allometric models used in the calculations (Holdaway and others 2014). We quantitatively incorporated all these sources of uncertainty in the calculation of confidence intervals for the estimates of mean biomass stock and biomass change using a Monte Carlo simulation approach following Holdaway and others (2014). Simulations were run using data from all 874 plots for both 2002-2007 and 20092014. We ran a total of 1000 simulations that were randomly sampled from known distributions of the various sources of uncertainty and calculated the mean and standard deviation of biomass and biomass change for each simulation, giving a distri- bution of values for each plot. We then used bootstrapping to calculate the median values among plots of both the mean and the standard deviation, and the $95 \%$ bias-corrected accelerated percentiles of these distributions. This provided simulated estimates of uncertainty that incorporated measurement error, model uncertainty and sampling uncertainty.

\section{Ecosystem Drivers}

Data for potential drivers of biomass and net biomass change were obtained for each plot. Mean annual temperature (MAT) and rainfall (MAR) were sourced from the Land Environments of New Zealand climate layers, which have a resolution of $25 \mathrm{~m}$ (Leathwick and others 2003). MAT ranged from 5.3 to $15.8^{\circ} \mathrm{C}$ (mean $10.0^{\circ} \mathrm{C}$ ), and MAR ranged from 624 to $9250 \mathrm{~mm}$ (mean $2446 \mathrm{~mm}$ ) (Figure S1 in Electronic Supplementary Material). Plots were stratified into old-growth and secondary (that is, successional) forest based on their species composition, using a quantitative classification derived from the same dataset (Wiser and others 2011; Table S1 and Figure S2 in Electronic Supplementary Material). Because this stratification is based on species composition rather than forest structural attributes, small-scale gap dynamics of old-growth forest (for example, stand replacement by canopy tree species following localised disturbance or natural tree mortality) are assumed to occur within our "old-growth" forest type ( $N=738$ plots). Secondary forests, however, comprise seral species only and are therefore defined as transitional communities that will, in the absence of large disturbances, develop into old-growth forests ( $N=136$ plots). We chose to use this communitybased classification of old-growth and secondary forest rather than relying on structural or age-based definitions because it provides a means of objective classification of uneven aged forests that is independent of biomass or measurements used to calculate biomass. Secondary forests have arisen from a stand-replacing disturbance event prior to plot establishment that was either natural (for example, landslide, earthquake) or anthropogenic (for example, fire). Tree diversity (species richness) ranged from 0 to 24 species per 0.04-ha plot (mean ten species).

Community-weighted leaf nitrogen concentrations were used as a proxy for site fertility. These were calculated for each plot using database of species trait values (S.J.R. and D.A.P., unpublished data) in combination with height tier $(0-30 \mathrm{~cm}$; $>30 \mathrm{~cm}-2 \mathrm{~m}$; > 2-5 m; >5-12 m; >12-25 m; > 
$25 \mathrm{~m}$; epiphyte) and cover class data (based on a modified Braun-Blanquet cover-abundance scale; $1=<1 \%, 2=1-5 \%, 3=6-25 \%, 4=>26-50 \%$, $5=>51-75 \%, 6=>76-100 \%)$ for all vascular plant species. Cover scores within each height tier were converted to the midpoint of the percentage cover range, for that cover-abundance class, and summed across tiers (Wiser and others 2011). Species trait values were then weighted by their total cover across all height tiers to obtain the community-weighted mean trait value for each plot. Although only a single mean trait value was used for each species, species turnover at a national scale was high and our metric effectively captures the nutrient status of the plant community by including understorey and herbaceous species that have high species turnover and are indicative of site fertility (Richardson and others 2004). Species-level trait data were available for $15.2 \%$ of the species in our dataset, corresponding to $82.4 \%$ of the total cover. For species without trait data, genus- or family-level trait values were used.

Data on past anthropogenic disturbances ("past disturbance") were collected at the time of plot establishment (2002-2007) from the observed evidence of historical activities such as logging, fire, land clearance, mining or grazing. These data were combined into a binary response variable to indicate whether the plot had been affected by human activities. A total of 273 plots $(31.2 \%)$ were identified as being subject to past disturbance, including $20 \%$ of old-growth forest plots. "Recent disturbance" (both anthropogenic and natural) that occurred during the measurement interval was quantified using plot data for live trees. Plots that exhibited a decline in basal area and a decrease in mean tree size were considered to have been disturbed during the measurement interval (Coomes and Allen 2007). This definition focuses on standlevel effects of disturbance (death of large trees), rather than the presence of individual disturbance agents (for example, insects, windstorms, fire, earthquakes), as the latter were not recorded during the field inventory. Our definition of recent disturbance does not distinguish between disturbance-induced mortality from age-related mortality of large trees (for example, Vanderwel and others 2013) or mortality driven by natural and anthropogenic disturbance. Disturbances that occurred during the survey measurement interval are very likely to have different impacts on observed carbon dynamics when compared with the legacy effects of past disturbances (that is, those prior to the initial measurement). The effects of recent disturbance on stand biomass depend on the scale of disturbance and relative rates of both deadwood decay and live tree regrowth, and can thus result in either a net gain or a net loss of biomass over the measurement interval (Mason and others 2013). On the basis of these criteria, a total of 143 plots $(16.4 \%)$ were disturbed during the 7-year measurement interval, with an annual disturbance probability of $2.3 \%$.

\section{Statistical Analyses}

We used structural equation modelling (Grace 2006) to simultaneously evaluate the direct and indirect effects of the potential explanatory variables on biomass and net biomass change. Structural equation models were chosen because of their ability to quantify complex direct and indirect effects in multivariate systems (for example, Durán and others 2015; Poorter and others 2015). Our initial model included all paths supported by ecological theory or published empirical data (Figure 2; Table S2 in Electronic Supplementary Material). This model was fitted separately to data from old-growth and secondary forest using a confirmatory modelling approach whereby data were compared to a single model to evaluate the strengths of the potential pathways (Grace 2006). We estimated the reliability (that is, measurement error) associated with biomass and net biomass change separately for both old-growth and secondary forests using the average correlation among

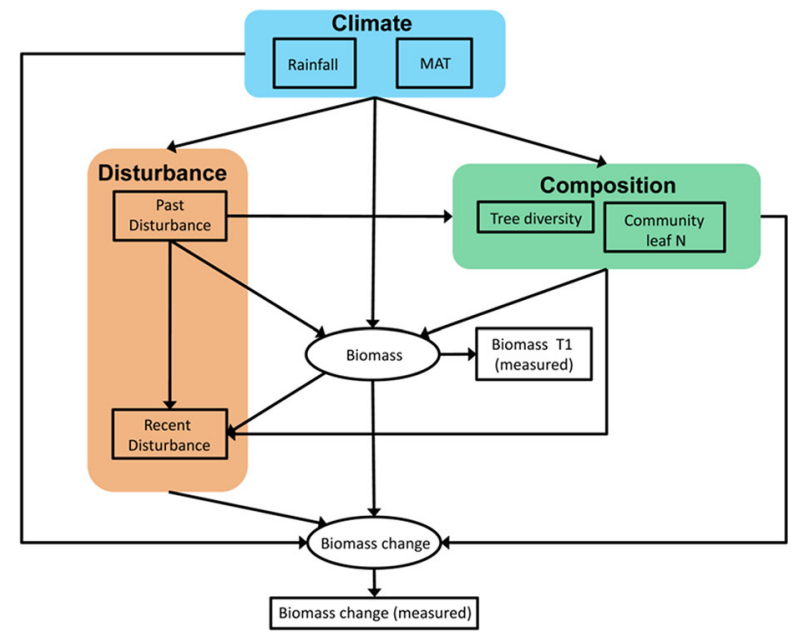

Figure 2. Path diagram showing all hypothesised regression paths tested by the structural equation model. Arrows to/from the edges of coloured areas represent both parameters inside the shaded area (for example, past disturbance potentially affects both tree diversity and community leaf nitrogen). Biomass $\mathrm{Tl}=$ biomass at first measurement (2002-2007). MAT mean annual temperature. 


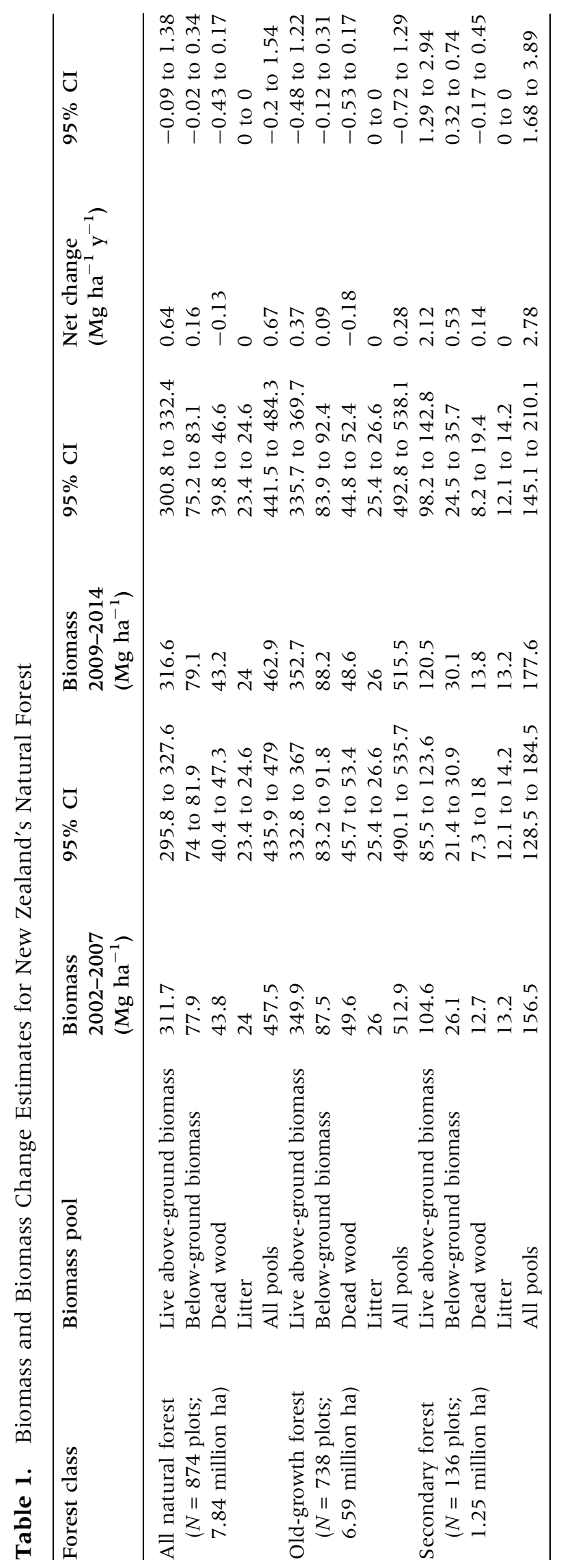

values from the Monte Carlo uncertainty simulation trials, and incorporated these into our model as latent variables (Grace 2006). The comparatively low reliability of our net biomass change estimates reflects the sensitivity of biomass change to measurement error (Holdaway and others 2014). Bivariate plots and generalised linear models were used to examine for evidence of non-linear (polynomial) relationships (Figure S3 and Figure S4 in Electronic Supplementary Material), and, where appropriate, these were incorporated into our model using composite variables (Grace 2006). Data were scaled to standardise variances prior to fitting the model using the lavaan package (Rosseel 2012) in R v 3.0.2 (R Development Core Team 2013). A single secondary forest data point was identified as a biologically unrealistic outlier (Figure S3 in Electronic Supplementary Material). Because this outlier was most likely caused by unresolvable measurement error, it was excluded from our structural equation models to avoid biasing the results. Results with and without this data point were qualitatively similar (that is, there was no change in the identity and direction of the significant paths and only minor changes in their relative strength), indicating that the model was robust. Weighted least squares estimation was used to allow for ordinal predictor variables and robust methods were used to calculate standard errors and fit indices to allow for deviations from multivariate normality (using the WLSM estimator; Rosseel 2012). Model fit was evaluated using $\chi^{2}$ tests and the root mean square error of approximation (RMSEA). $\chi^{2} P$ values greater than 0.05 and RMSEA confidence intervals that overlap zero indicate that the model is acceptable and that no additional significant paths can be added (Grace 2006). Total direct and indirect effects of each ecosystem predictor on biomass and net biomass change were calculated using the standardised path coefficients. Plot-level data used in these analyses are provided online at the Landcare Research Datastore (http://dx.doi.org/10.7931/J21V5BWC).

\section{RESUltS}

\section{Observed Biomass Trends}

National forest biomass density was $458 \mathrm{Mg} \mathrm{ha}^{-1}$ (95\% confidence interval 435-479) during 20022007 and 463 (442-484) $\mathrm{Mg} \mathrm{ha}^{-1}$ during 20092014 (Table 1). Multiplying these values by the total area of New Zealand's pre-1990 natural forests (ca. 7.84 million ha) gives a total biomass stock of 3.6 (3.4-3.8) Pg contained in the live biomass, 

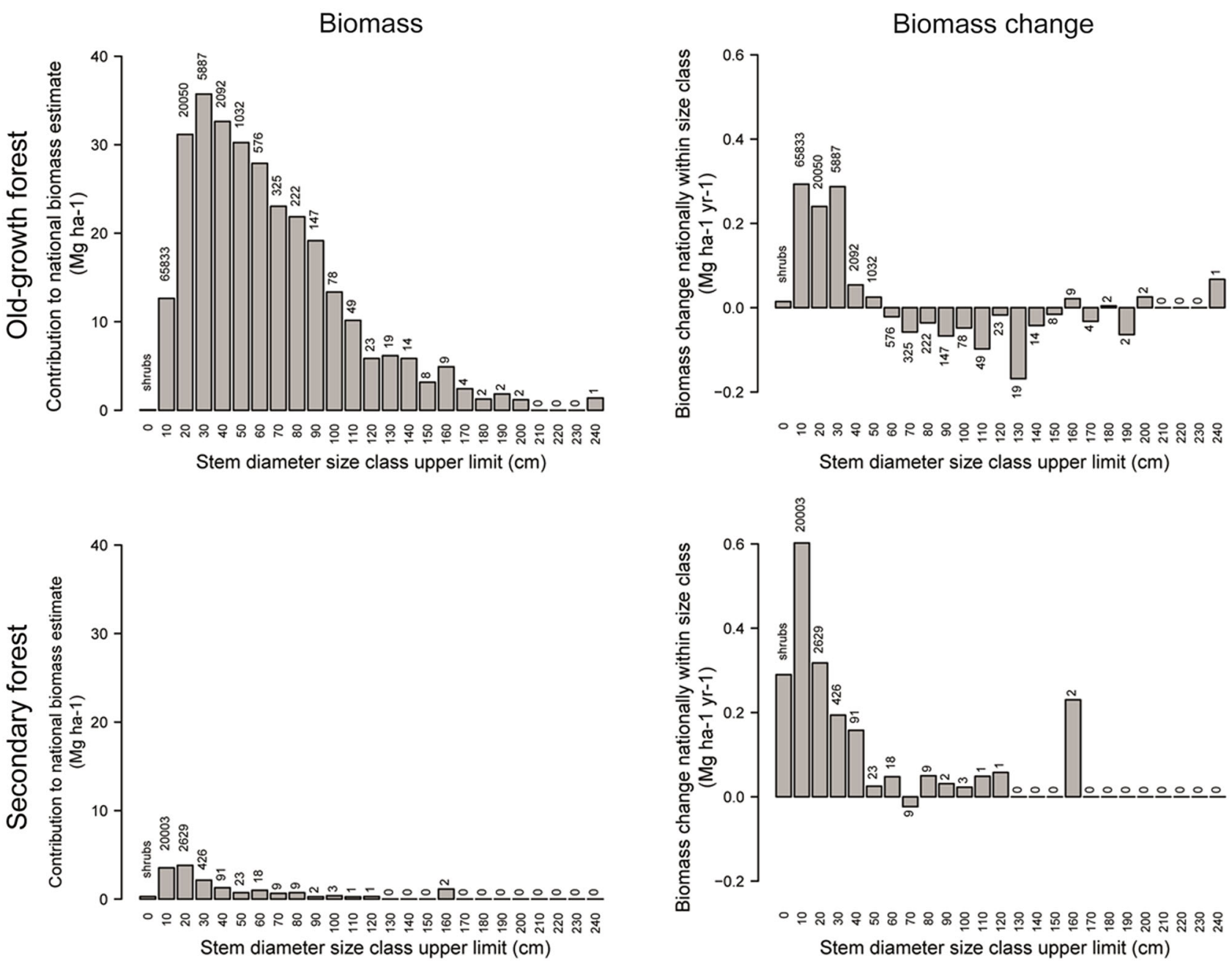

Figure 3. Distribution of live above-ground biomass during 2002-2007 and live above-ground biomass change (growth + recruitment - mortality) by tree size class between 2002-2007 and 2009-2014 measurement periods for both old-growth and secondary forests. Numbers represent total live stems in each size class at first measurement (2002-2007).

deadwood and litter pools. Secondary forests occupied 1.25 million ha (16\% of the landscape) and contained $6 \%(0.2 ; 0.16-0.23 \mathrm{Pg})$ of the total forest biomass stock. Old-growth forests occupied 6.59 million ha $(84 \%$ of the landscape) and contained $94 \%(3.4 ; 3.2-3.5 \mathrm{Pg})$ of the total forest biomass stock. Secondary forests were a net biomass sink (+2.78; $\left.1.68-3.89 \mathrm{Mg} \mathrm{ha}^{-1} \mathrm{y}^{-1}\right)$ over the period 2002-2014, whereas net biomass change in old-growth forests was statistically indistinguishable from zero $\left(+0.28 ;-0.72\right.$ to $\left.1.29 \mathrm{Mg} \mathrm{ha}^{-1} \mathrm{y}^{-1}\right)$. National-scale net biomass change was therefore dominated by secondary forests, characterised by a large number of rapidly growing smaller trees, rather than old-growth forests (Figure 3). Nationally, across both secondary and old-growth forests, small trees $(<10 \mathrm{~cm}$ diameter) accounted for $71.8 \%$ of all stems, representing just $5.1 \%(4.8-5.4)$ of the total live above-ground biomass, but were a net sink of $+0.34 \mathrm{Mg} \mathrm{ha}^{-1} \mathrm{y}^{-1}(0.28-0.40)$. In contrast, large trees $(\geq 60 \mathrm{~cm}$ diameter) comprised just $0.77 \%$ of all stems and contained $41.0 \%$ (36.645.4 ) of the total live above-ground biomass stocks, but were a (marginally significant) biomass source of $-0.40 \mathrm{Mg} \mathrm{ha}^{-1} \mathrm{y}^{-1}(-0.88-0.08)$.

\section{Ecosystem Drivers of Forest Change}

Structural equation models incorporating both direct and indirect drivers of biomass and biomass change were well supported for both old-growth and secondary forests [Figure 4; old-growth forest $\chi^{2}=9.8$, $d f=6, P=0.13$, RMSEA $=0.03(0-0.06)$; secondary forest $\chi^{2}=5.6, d f=6, P=0.47$, RMSEA $=0.00(0-$ $0.12)]$. Old-growth forest biomass was driven by a mixture of past disturbance, climate and composi- 
(A) Old-growth forest

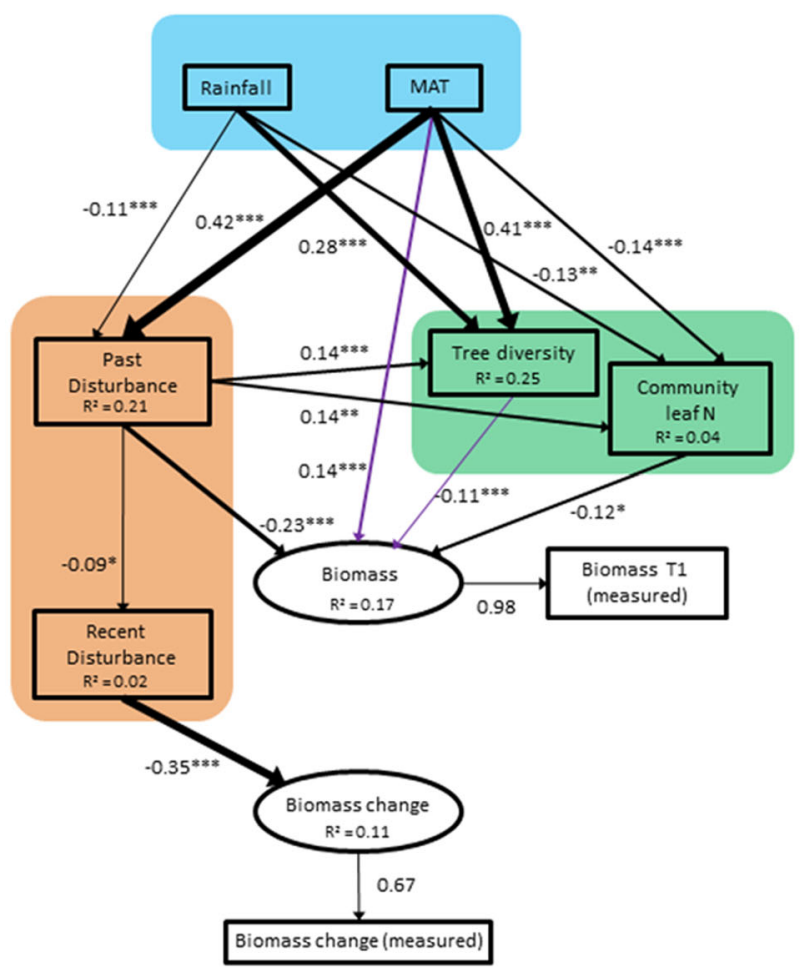

(B) Secondary forest

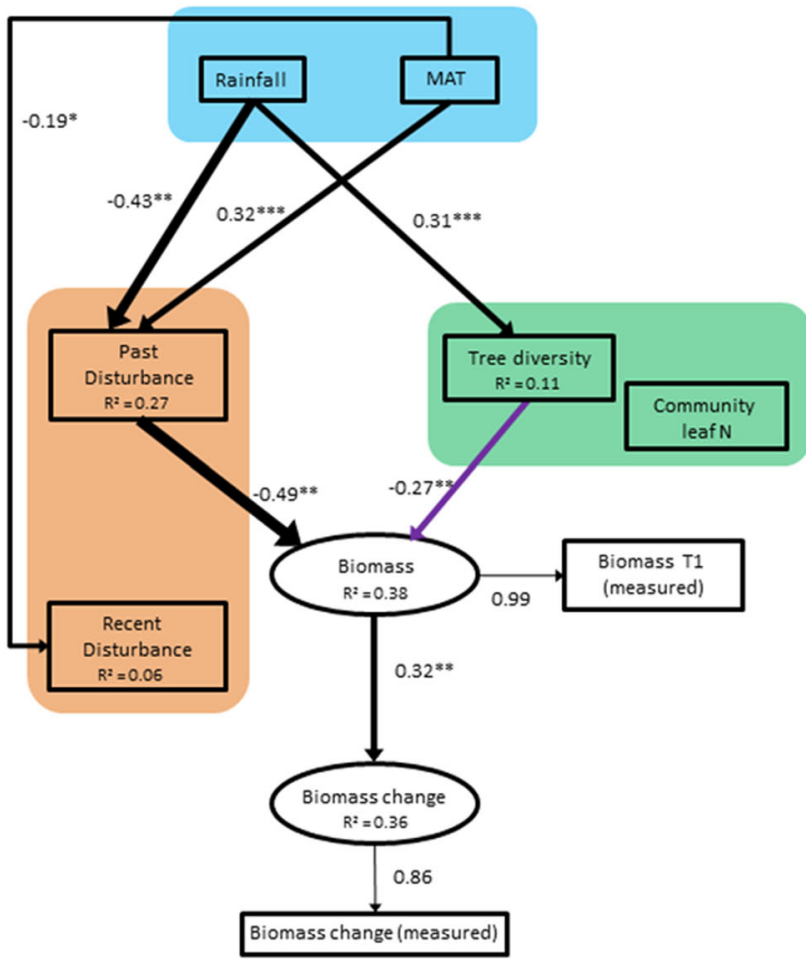

Figure 4. Structural equation models for old-growth and secondary forests. Standardised path coefficients for latent variables and significant $(P<0.05)$ regression paths are shown. Arrows represent the causal flow and the width of arrows (for regression paths) is scaled according to relationship strength. Boxes indicate measured predictor variables and ovals indicate latent variables. Biomass and biomass change were modelled as latent variables specifically to include the effects of quantified measurement error. Arrows between MAT and biomass, and tree diversity and biomass represent significant second-order polynomial relationships, which were fitted using composite variables. Both models had adequate model fit $\left[(\mathrm{A}) \chi^{2}=9.8, d f=6, P=0.13, \mathrm{RMSEA}=0.03(0-0.06) ;(\mathrm{B}) \chi^{2}=5.6, d f=6, P=0.47, \mathrm{RMSEA}=0.00(0-0.12)\right] . M A T$ mean annual temperature. $R^{2}$ coefficient of determination. ${ }^{*} P \leq 0.05,{ }^{*} P \leq 0.01, * * * P \leq 0.001$.

tional effects, whereas secondary forest biomass was more strongly and directly related to past disturbance (Figs. 4, 5). There was a direct, negative, humpshaped relationship between tree diversity and biomass, and this pattern was strongest in secondary forest (Figs. 4, 5; Figure S4 in Electronic Supplementary Material). Temperature and leaf nitrogen were directly related to biomass in old-growth forests but not in secondary forests.

Biomass was the only direct predictor of biomass change in secondary forests with biomass change being positively related to plot biomass (that is, higher biomass secondary forests gained more biomass per year). Temperature, rainfall, leaf nitrogen and past disturbance indirectly affected biomass change through their relationships with biomass (Figs. 4, 5). In contrast, recent disturbance was the only direct predictor of biomass change in oldgrowth forests, effectively decoupling biomass change from biomass, climate and compositional effects. Old-growth forests showed more signs of recent disturbance than secondary forests, with $18 \%$ of old-growth forest exhibiting declines in basal area and a decrease in mean tree size during the 7-year measurement period, compared with just $6 \%$ of secondary forest. This pattern corresponds with our finding that large $(>60 \mathrm{~cm} \mathrm{D})$ diameter classes, which are more abundant in old-growth forest, lost more biomass due to mortality than they gained due to ingrowth (Figure 3). Overall net biomass change in old-growth forests affected by recent disturbance was $-4.54 \mathrm{Mg} \mathrm{ha}^{-1} \mathrm{y}^{-1}(95 \% \mathrm{CI}-2.56$ to -6.52$)$, compared with $1.36 \mathrm{Mg} \mathrm{ha}^{-1} \mathrm{y}^{-1}(95 \%$ CI 0.68 2.04) for old-growth forests not exhibiting signs of recent disturbance.

\section{Discussion}

This study provides the first direct quantification of net changes in natural forest biomass in southern 

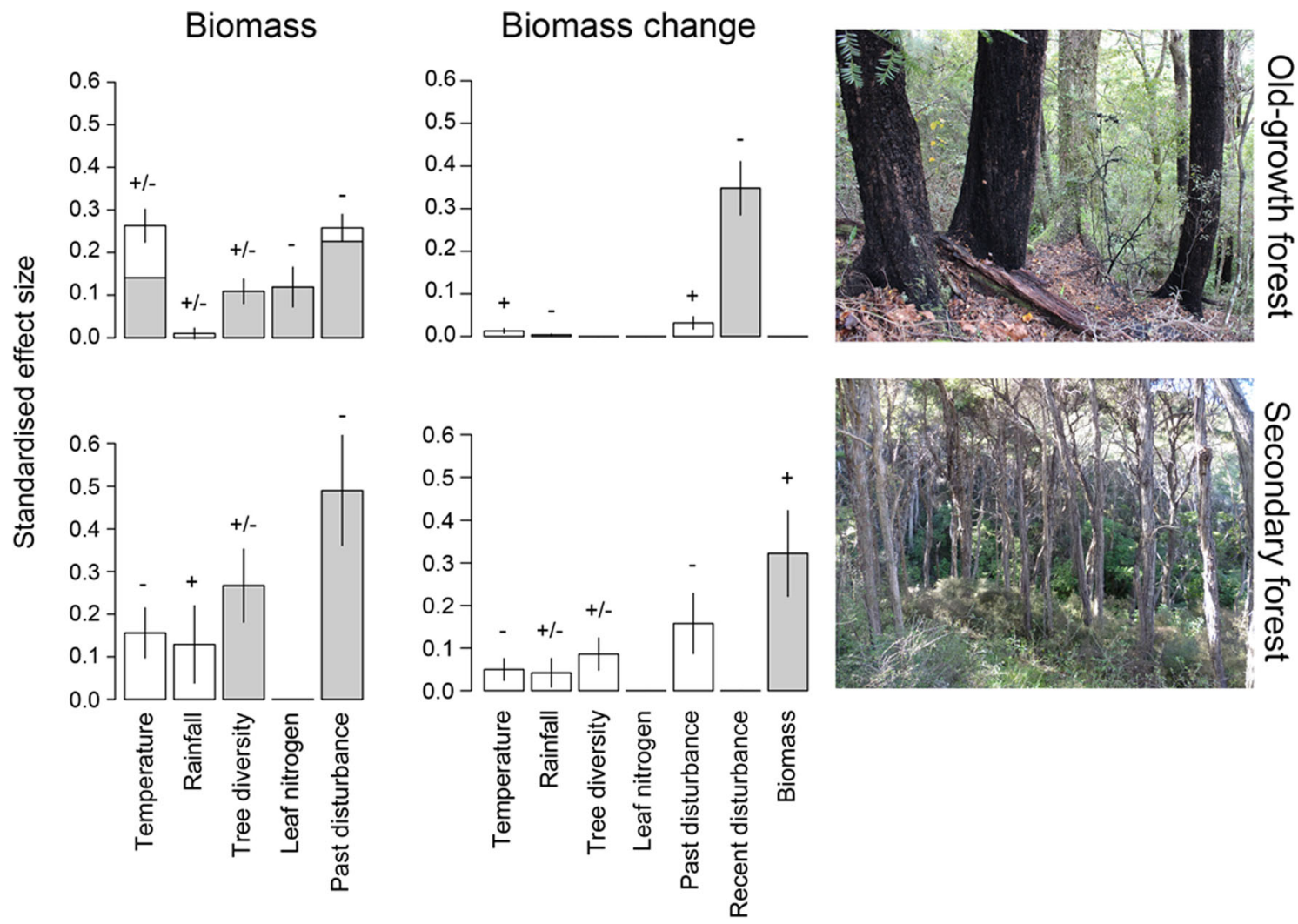

Figure 5. Standardised effect size for the individual predictors of biomass and net biomass change from the structural equation models for old-growth and secondary forests. The shaded part of the bar represents direct effects and the clear portion represents indirect effects. Standardised effect size is calculated from significant paths only. Direction of the effects is indicated as negative $(-)$, positive $(+)$ or multidirectional $( \pm)$ for effects with polynomial components. Error bars $( \pm \mathrm{SE})$ are presented for the total (direct + indirect) effect size. Photo credits: R.J.H. and Susan Wiser.

temperate forests based on representative sampling of both live stem and deadwood pools across a broad geographic region. We show that the drivers of biomass and biomass change differ between secondary and old-growth forests. Secondary forests were net biomass sinks, whereas old-growth forests were biomass neutral over the last decade. In old-growth forests, changes in biomass over time were directly related to our measure of recent disturbance and were unrelated to forest biomass. In contrast, secondary forest biomass change was determined by more complex interactions involving biomass, climate, community composition and past disturbance. Our results challenge the commonly held assumption that productivity is strongly positively related to biomass in old-growth forests (for example, Chisholm and others 2013; Poorter and others 2015) and reinforce the prominent influence of composition, recent disturbance and the legacy effects of past anthropogenic disturbance on broad-scale patterns of forest biomass change (Caspersen and others 2000; Coomes and others 2014).

\section{Secondary Forests are the Dominant Biomass Sink at a National Scale}

Our finding that secondary forests were net biomass sinks at the national scale indicates that these forests are systematically recovering from a legacy of previous biomass loss, in agreement with recent evidence from the Neotropics (Poorter and others 2016). However, our observed lack of carbon sink in old-growth forests differs from some previous studies that found old-growth forests to be a carbon sink (for example, Luyssaert and others 2008; Lewis and others 2009; Pan and others 2011). We note, however, that while our analyses are based on a systematic sample of the forest population and include changes in the deadwood pool, we do not assess the potential contribution of the soil carbon pool (which was accounted for in Luyssaert and others 2008). The most likely explanation for our observed differences in net biomass change between old-growth and secondary forests is stand development processes (Coomes and others 2012). 
Secondary forests comprised smaller trees that are less prone to some disturbances (for example, wind damage, which is common in New Zealand) than larger trees. Secondary forests are also more likely to exhibit a strong growth signal (for example, an increase in mean tree size and total basal area), with mortality being dominated by competitive thinning processes that result in the death of smaller (low-biomass) individuals. These factors would enhance the resistance and resilience of secondary forests to some forms of disturbance, increasing their biomass resilience (Poorter and others 2016). In contrast, old-growth forests tend to be dominated by fewer, larger individuals and are more likely to be at dynamic equilibrium, with the high biomass production rates of individual large trees (Stephenson and others 2014) being balanced by biomass loss due to mortality and decay. Across New Zealand, large trees (that is, $>60 \mathrm{~cm} \mathrm{D)} \mathrm{comprised} \mathrm{only} 0.77 \%$ of the total stems in old-growth forest, but contained $40 \%$ of the total biomass stocks. This highlights the potential vulnerability of live tree forest biomass in old-growth forests to large-scale disturbances that reduce the density of large trees in the landscape (Hicke and others 2012).

\section{Disturbance is a Direct Driver of Large- Scale Biomass Change}

Disturbance is being increasingly recognised as a major driver of forest ecosystem processes and forest carbon budgets (Caspersen and others 2000; Coomes and others 2012; Erb and others 2013; Seidl and others 2014; Nowacki and Abrams 2015). Consistent with this view, our models suggest that past anthropogenic disturbance and recent disturbance (mortality of large trees) are the most important drivers of forest biomass and biomass change at a national scale (Figure 4). Anthropogenic forest disturbance is a global issue, mainly through deforestation, but also through selective logging, understory fires and fragmentation which have been shown to cause a decline in forest biomass density of up to $40 \%$ in the Amazon Basin (Berenguer and others 2014). Natural disturbances may be even more severe because they can affect large tracts of high-biomass, old-growth forest that are otherwise largely unaffected by direct human activity, and interactions between climate change and natural disturbance may exacerbate such effects (for example, Kurz and others 2008; Phillips and others 2009; Allen and others 2010).

Climate is widely reported and predicted to affect forest biomass storage both directly through plant physiology processes and indirectly through changes in forest composition or structure (Coomes and others 2014; Brienen and others 2015; Nowacki and Abrams 2015; Pederson and others 2015). Over the gradients investigated here, we found no evidence for consistent direct effects of climate on forest biomass or biomass change. Rather, our analyses revealed that past disturbance acts as an intermediate factor that links climate to forest biomass and net biomass change (Figs. 4, 5). For example, past (anthropogenic) disturbance typically occurred in relatively warmer, drier climates that are more suitable for human habitation and thus widespread forest loss (Perry and others 2012); similar biogeographic relationships between climate and past anthropogenic disturbance occur globally (Caspersen and others 2000; Nowacki and Abrams 2015). Disentangling past anthropogenic disturbance from the direct effects of climate on net biomass change is therefore essential to accurately forecast the future effects of climate change in forest systems (for example, Ghimire and others 2015; Nowacki and Abrams 2015; Pederson and others 2015).

\section{Scalability of Plot Networks over Broad Geographical Regions}

Vegetation plot networks have been widely used to generate empirical data for evaluating forest dynamics and the drivers of biomass change (for example, Caspersen and others 2000; Lewis and others 2009; Brienen and others 2015; Poorter and others 2015). However, an underlying assumption of this approach is that plots capture variation in forest processes at the appropriate spatial and temporal scales. We used a national plot network to provide spatially representative data across broad environmental gradients, but, by necessity, this entailed using small plots $\left(400 \mathrm{~m}^{2}\right)$. Small plots may exaggerate the effects of relatively small-scale processes such as recent canopy disturbance. The national biomass and biomass change estimates are robust to these effects because of the relatively large number of plots and the inclusion of measurement error in the confidence intervals (Holdaway and others 2014), but, as with any plot-based analysis, our assessment of how multiple drivers interact to determine forest biomass change is scale dependent (for example, Chisholm and others 2013). On the other hand, the use of larger plots comes at a significant trade-off in terms of spatial representativeness, and for practical reasons larger plots are fewer in number and tend to be located on relatively accessible-and hence biased-locations. 
A larger amount of smaller plots is generally more cost effective for reducing uncertainty than increasing plot size but reducing the total number of plots (Keller and others 2001). Larger plots also often have a higher stem diameter cut-off than the value of $2.5 \mathrm{~cm}$ employed here and thus cannot be used to assess the response of smaller tree size classes. Our results demonstrate that these smaller $(<10 \mathrm{~cm}$ D) size classes contribute meaningfully to the overall biomass change in both old-growth and secondary forests (Figure 3). Moreover, the identity and dynamics of these smaller stems may determine future forest structure, composition and function (Chase 2010; Coomes and others 2014). This suggests that the role of smaller stem size classes in biomass change needs to be considered alongside the trade-off in plot area.

A prediction that can be derived from our analysis is that the expected increase in frequency or intensity of future disturbance regimes (Reichstein and others 2013; Ghimire and others 2015) is likely to result in net biomass loss in old-growth forests, but will have little or no effect on the secondary forest biomass sink (Figure 5). The prediction for old-growth forests is consistent with a recent study by Brienen and others (2015) which suggests that the carbon sink in Amazon old-growth forest is already declining due to an increase in mortality processes. However, that study did not quantify changes to the deadwood pool. As large trees die, a significant portion of the total biomass pool is transferred to the deadwood pool and lost over time to the atmosphere through decay. Net biomass change depends on the relative rates of deadwood decay and forest regrowth, and evidence from temperate forests suggests that for disturbed stands regrowth rates are insufficient to prevent significant, long-term (multi-decadal) reductions in carbon in old-growth forests (Mason and others 2013). Secondary forests are predicted to be more resistant to increases in disturbance regimes (Figure 5) and now occupy a significant part of the global forest landscape (for example, Berenguer and others 2014), but have tended to be overlooked in many forest plot networks, particularly in the tropics (for example, Brienen and others 2015; Poorter and others 2015). The lack of a whole-landscape sampling design limits the ability to scale the results of such studies to broad geographical regions such as the Amazon Basin.

\section{Future Methodological Improvements}

There are three areas where our analyses could be improved through additional data collection. First, the below-ground biomass (BGB) fraction is poorly quantified compared to other biomass pools. This limitation occurs in similar large-scale studies (for example, Powell and others 2014; Brienen and others 2015) and reflects a global lack of data on below-ground woody biomass in forests (Phillips and Watson 1994; Cairns and others 1997). We assume that BGB is a constant fraction of live AGB, and this approach does not explicitly include below-ground dead coarse woody biomass. Our results therefore underestimate BGB, especially in disturbed stands. Second, collection of disturbance data during field measurement stage, or through remote sensing, would provide a more independent assessment of recent disturbance and facilitate the attribution of disturbance agents (for example, Allen and others 1999; Hermosilla and others 2015), improving our ability to model disturbance processes and quantify carbon change following both natural and anthropogenic disturbance. Third, our old-growth and secondary forest definition is based on community composition, targeted at separating highly successional forest communities dominated by seral species that occur following stand-replacing disturbances (for example, landslide, historical land clearance and fire), from forests that are compositionally mature with periodic canopy-replacing gap dynamics (Wiser and others 2011). The development and use of alternative classifications of old-growth and secondary forest based on structural attributes and stand age would improve comparability with other studies and unify compositional and structural classification approaches (Burrascano and others 2013; Reilly and Spies 2015). Our results provide the best estimates to date on carbon stock and carbon change in southern temperate natural forests and provide new insights into the broad-scale drivers of biomass change. Analyses of other similar datasets (for example, FIA data) using similar SEM models would provide a valuable test of the generalities of our findings.

\section{Concluding Remarks}

Understanding of the broad-scale drivers of forest biomass change is essential for forecasting future forest changes and their implications for the global carbon cycle (for example, Friend and others 2014; Seidl and others 2014). Our results, based on nationally representative plot network, identify contrasting drivers of net biomass change for secondary and old-growth forests and highlight the importance of disturbance and disturbance history in determining broad-scale patterns of forest biomass 
change. The significant biomass sink observed in secondary forest suggests that opportunities exist to increase forest biomass storage through large-scale facilitation of secondary forest succession in deforested areas. Efforts, such as REDD+ (Miles and Kapos 2008), that aim to minimise future anthropogenic forest disturbances will be important to maintain the carbon balance of old-growth forests. Further research on the broad-scale balance between secondary and old-growth forests is essential to inform our understanding of the global forest biomass sink.

\section{ACKNOWLEDGEMENTS}

We thank the New Zealand Ministry for the Environment for leading the LUCAS programme over the last two decades and all those involved in the natural forest plot network design, data collection and database management, including New Zealand's National Vegetation Survey Databank (NVS). Special thanks go to I. Payton, J. Buswell, M. McKay, E. Wright, R. Allen, P. Beets, L. Garrett, S. Beadel, S. Husheer and the hundreds of dedicated field staff involved in the programme. S. McNeill and P. Bellingham and two anonymous reviewers provided helpful comments on earlier versions of this manuscript. This research was supported by the New Zealand Ministry of Business, Innovation and Employment Core funding to Crown Research Institutes and the New Zealand Ministry for the Environment.

\section{OPEN ACCESS}

This article is distributed under the terms of the Creative Commons Attribution 4.0 International License (http://creativecommons.org/licenses/by/ $4.0 /$ ), which permits unrestricted use, distribution, and reproduction in any medium, provided you give appropriate credit to the original author(s) and the source, provide a link to the Creative Commons license, and indicate if changes were made.

\section{REFERENCES}

Allen RB, Bellingham PJ, Wiser SK. 1999. Immediate damage by an earthquake to a temperate montane forest. Ecology 80:708-14.

Allen CD, Macalady AK, Chenchouni H, Bachelet D, McDowell N, Vennetier M, Kitzberger T, Rigling A, Breshears DD, Hogg EH, Gonzalez P, Fensham R, Zhang Z, Castro J, Demidova N, Lim J-H, Allard G, Running SW, Semerci A, Cobb N. 2010. A global overview of drought and heat-induced tree mortality reveals emerging climate change risks for forests. For Ecol Manag 259:660-84.

Beets PN, Kimberley MO, Oliver GR, Pearce SH, Graham JD, Brandon A. 2012. Allometric Equations for estimating carbon stocks in natural forest in New Zealand. Forests 3:818-39.
Berenguer E, Ferreira J, Gardner TA, Aragão LEOC, De Camargo PB, Cerri CE, Durigan M, Oliveira RCD, Vieira ICG, Barlow J. 2014. A large-scale field assessment of carbon stocks in human-modified tropical forests. Glob Change Biol 20:3713-26.

Brienen RJW, Phillips OL, Feldpausch TR, Gloor E, Baker TR, Lloyd J, Lopez-Gonzalez G, Monteagudo-Mendoza A, Malhi $\mathrm{Y}$, Lewis SL, Vasquez Martinez R, Alexiades M, Alvarez Davila E, Alvarez-Loayza P, Andrade A, Aragao LEOC, Araujo-Murakami A, Arets EJMM, Arroyo L, Aymard CGA, Banki OS, Baraloto C, Barroso J, Bonal D, Boot RGA, Camargo JLC, Castilho CV, Chama V, Chao KJ, Chave J, Comiskey JA, Cornejo Valverde F, da Costa L, de Oliveira EA, Di Fiore A, Erwin TL, Fauset S, Forsthofer M, Galbraith DR, Grahame ES, Groot N, Herault B, Higuchi N, Honorio Coronado EN, Keeling H, Killeen TJ, Laurance WF, Laurance S, Licona J, Magnussen WE, Marimon BS, Marimon-Junior BH, Mendoza C, Neill DA, Nogueira EM, Nunez P, Pallqui Camacho NC, Parada A, Pardo-Molina G, Peacock J, PenaClaros M, Pickavance GC, Pitman NCA, Poorter L, Prieto A, Quesada CA, Ramirez F, Ramirez-Angulo H, Restrepo Z, Roopsind A, Rudas A, Salomao RP, Schwarz M, Silva N, Silva-Espejo JE, Silveira M, Stropp J, Talbot J, ter Steege H, Teran-Aguilar J, Terborgh J, Thomas-Caesar R, Toledo M, Torello-Raventos M, Umetsu RK, van der Heijden GMF, van der Hout P, Guimaraes Vieira IC, Vieira SA, Vilanova E, Vos VA, Zagt RJ. 2015. Long-term decline of the Amazon carbon sink. Nature 519:344-8.

Burrascano S, Keeton WS, Sabatini FM, Blasi C. 2013. Commonality and variability in the structural attributes of moist temperate old-growth forests: a global review. For Ecol Manag 291:458-79.

Canham CD. 2014. Disequilibrium and transient dynamics, disentangling responses to climate change versus broader anthropogenic impacts on temperate forests of eastern North America. In: Coomes DA, Burslem DFRP, Simonson WD, Eds. Forests and global change. Cambridge, UK: Cambridge University Press. p 109-28.

Caspersen JP, Pacala SW, Jenkins JC, Hurtt GC, Moorcroft PR, Birdsey RA. 2000. Contributions of land-use history to carbon accumulation in U.S. forests. Science 290:1148-51.

Chase JM. 2010. Stochastic community assembly causes higher biodiversity in more productive environments. Science 328:1388-91.

Chambers JQ, Negrón-Juárez RI, Hurtt GC, Marra DM, Higuchi N. 2009. Lack of intermediate-scale disturbance data prevents robust extrapolation of plot-level tree mortality rates for oldgrowth tropical forests. Ecol Lett 12:E22-5.

Cairns MA, Brown S, Helmer EH, Baumgardner GA. 1997. Root biomass allocation in the world's upland forests. Oecologia 111:1-11.

Coomes DA, Allen RB. 2007. Mortality and tree-size distributions in natural mixed-age forests. J Ecol 95:27-40.

Coomes DA, Allen RB, Scott NA, Goulding C, Beets P. 2002. Designing systems to monitor carbon stocks in forests and shrublands. For Ecol Manag 164:89-108.

Coomes DA, Flores O, Holdaway R, Jucker T, Lines ER, Vanderwel MC. 2014. Wood production response to climate change will depend critically on forest composition and structure. Glob Change Biol 20:3632-45.

Coomes DA, Holdaway RJ, Kobe RK, Lines ER, Allen RB. 2012. A general integrative framework for modelling woody biomass production and carbon sequestration rates in forests. $\mathrm{J}$ Ecol 100:42-64. 
Chisholm RA, Muller-Landau HC, Abdul Rahman K, Bebber DP, Bin Y, Bohlman SA, Bourg NA, Brinks J, Bunyavejchewin S, Butt N, Cao H, Cao M, Cárdenas D, Chang L-W, Chiang J-M, Chuyong G, Condit R, Dattaraja HS, Davies S, Duque A, Fletcher C, Gunatilleke N, Gunatilleke S, Hao Z, Harrison RD, Howe R, Hsieh C-F, Hubbell SP, Itoh A, Kenfack D, Kiratiprayoon S, Larson AJ, Lian J, Lin D, Liu H, Lutz JA, Ma K, Malhi Y, McMahon S, McShea W, Meegaskumbura M, Mohd. Razman S, Morecroft MD, Nytch CJ, Oliveira A, Parker GG, Pulla S, Punchi-Manage R, Romero-Saltos H, Sang W, Schurman J, Su S-H, Sukumar R, Sun IF, Suresh HS, Tan S, Thomas D, Thomas S, Thompson J, Valencia R, Wolf A, Yap S, Ye W, Yuan Z, Zimmerman JK. 2013. Scale-dependent relationships between tree species richness and ecosystem function in forests. J Ecol 101:1214-24.

Durán SM, Sánchez-Azofeifa GA, Rios RS, Gianoli E. 2015. The relative importance of climate, stand variables and liana abundance for carbon storage in tropical forests. Glob Ecol Biogeogr 24:939-49.

Erb K-H, Kastner T, Luyssaert S, Houghton RA, Kuemmerle T, Olofsson P, Haberl H. 2013. Bias in the attribution of forest carbon sinks. Nat Clim Change 3:854-6.

Fernández-Martínez M, Vicca S, Janssens IA, Sardans J, Luyssaert S, Campioli M, Chapin FSIII, Ciais P, Malhi Y, Obersteiner M, Papale D, Piao SL, Reichstein M, Roda F, Penuelas J. 2014. Nutrient availability as the key regulator of global forest carbon balance. Nat Clim Change 4:471-6.

Fisher JI, Hurtt GC, Thomas RQ, Chambers JQ. 2008. Clustered disturbances lead to bias in large-scale estimates based on forest sample plots. Ecol Lett 11:554-63.

Flores O, Coomes DA. 2011. Estimating the wood density of species for carbon stock assessments. Methods Ecol Evol 2:214-20.

Friend AD, Lucht W, Rademacher TT, Keribin R, Betts R, Cadule P, Ciais P, Clark DB, Dankers R, Falloon PD, Ito A, Kahana R, Kleidon A, Lomas MR, Nishina K, Ostberg S, Pavlick R, Peylin P, Schaphoff S, Vuichard N, Warszawski L, Wiltshire A, Woodward FI. 2014. Carbon residence time dominates uncertainty in terrestrial vegetation responses to future climate and atmospheric $\mathrm{CO} 2$. Proc Natl Acad Sci USA $111: 3280-5$.

Ghimire B, Williams CA, Collatz GJ, Vanderhoof M, Rogan J, Kulakowski D, Masek JG. 2015. Large carbon release legacy from bark beetle outbreaks across Western United States. Glob Change Biol 21:3087-101.

Grace J. 2006. Structural equation modeling and natural systems. Cambridge, UK: Cambridge University Press.

Hermosilla T, Wulder MA, White JC, Coops NC, Hobart GW. 2015. Regional detection, characterization, and attribution of annual forest change from 1984 to 2012 using Landsatderived time-series metrics. Remote Sens Environ 170:12132.

Hicke JA, Allen CD, Desai AR, Dietze MC, Hall RJ, Hogg EH, Kashian DM, Moore D, Raffa KF, Sturrock RN, Vogelmann J. 2012. Effects of biotic disturbances on forest carbon cycling in the United States and Canada. Glob Change Biol 18:7-34.

Holdaway R, McNeill S, Mason NH, Carswell F. 2014. Propagating uncertainty in plot-based estimates of forest carbon stock and carbon stock change. Ecosystems 17:627-40.

Kalis AJ, Merkt J, Wunderlich J. 2003. Environmental changes during the Holocene climatic optimum in central Europe-human impact and natural causes. Quat Sci Rev 22:33-79.
Keller M, Palace M, Hurtt G. 2001. Biomass estimation in the Tapajos National Forest, Brazil: Examination of sampling and allometric uncertainties. For Ecol Manag 154:371-82.

Kurz WA, Stinson G, Rampley GJ, Dymond CC, Neilson ET. 2008. Risk of natural disturbances makes future contribution of Canada's forests to the global carbon cycle highly uncertain. Proc Natl Acad Sci USA 105:1551-5.

Leathwick JR, Wilson G, Rutledge D, Wardle P, Morgan F, Johnston K, McLeod M, Kirkpatrick R. 2003. Land environments of New Zealand. Auckland: David Bateman.

Lewis SL, Lopez-Gonzalez G, Sonke B, Affum-Baffoe K, Baker TR, Ojo LO, Phillips OL, Reitsma JM, White L, Comiskey JA, Djuikouo KMN, Ewango CEN, Feldpausch TR, Hamilton AC, Gloor M, Hart T, Hladik A, Lloyd J, Lovett JC, Makana J-R, Malhi Y, Mbago FM, Ndangalasi HJ, Peacock J, Peh KSH, Sheil D, Sunderland T, Swaine MD, Taplin J, Taylor D, Thomas SC, Votere R, Woll H. 2009. Increasing carbon storage in intact African tropical forests. Nature 457:1003-6.

Luyssaert S, Schulze ED, Borner A, Knohl A, Hessenmoller D, Law BE, Ciais P, Grace J. 2008. Old-growth forests as global carbon sinks. Nature 455:213-15.

Mason NWH, Bellingham PJ, Carswell FE, Peltzer DA, Holdaway RJ, Allen RB. 2013. Wood decay resistance moderates the effects of tree mortality on carbon storage in the indigenous forests of New Zealand. For Ecol Manag 305:177-88.

McGlone MS. 1989. The Polynesian settlement of New Zealand in relation to environmental and biotic changes. $\mathrm{N} \mathrm{Z} \mathrm{J} \mathrm{Ecol}$ $12: 115-29$.

Michaletz ST, Cheng D, Kerkhoff AJ, Enquist BJ. 2014. Convergence of terrestrial plant production across global climate gradients. Nature 512:39-43.

Miles L, Kapos V. 2008. Reducing greenhouse gas emissions from deforestation and forest degradation: global land-use implications. Science 320:1454-5.

Ministry for the Environment. 2012. Land use and carbon analysis system natural forest data collection manual. Wellington: Ministry for the Environment.

Ministry for the Environment. 2014. New Zealand greenhouse gas inventory 1990-2012. Wellington: Ministry for the Environment.

Muller-Landau HC, Detto M, Chisholm RA, Hubbell SP, Condit R. 2014. Detecting and projecting changes in forest biomass from plot data. In: Coomes DA, Burslem DFRP, Simonson WD, Eds. Forests and global change. Cambridge, UK: Cambridge University Press. p 381-415.

Myers N, Mittermeier RA, Mittermeier CG, da Fonseca GAB, Kent J. 2000. Biodiversity hotspots for conservation priorities. Nature 403:853-8.

Nowacki GJ, Abrams MD. 2015. Is climate an important driver of post-European vegetation change in the Eastern United States? Glob Change Biol 21:314-34.

Pan YD, Birdsey RA, Fang JY, Houghton R, Kauppi PE, Kurz WA, Phillips OL, Shvidenko A, Lewis SL, Canadell JG, Ciais P, Jackson RB, Pacala SW, McGuire AD, Piao SL, Rautiainen A, Sitch S, Hayes D. 2011. A large and persistent carbon sink in the world's forests. Science 333:988-93.

Payton IJ, Newell CL, Beets PN. 2004. New Zealand Carbon Monitoring system indigenous forest and shrubland data collection manual. Christchurch: Caxton Press.

Pederson N, D'Amato AW, Dyer JM, Foster DR, Goldblum D, Hart JL, Hessl AE, Iverson LR, Jackson ST, Martin-Benito D, McCarthy BC, McEwan RW, Mladenoff DJ, Parker AJ, Shu- 
man B, Williams JW. 2015. Climate remains an important driver of post-European vegetation change in the eastern United States. Glob Change Biol 21:2105-10.

Perry GLW, Wilmshurst JM, McGlone MS, McWethy DB, Whitlock C. 2012. Explaining fire-driven landscape transformation during the Initial Burning Period of New Zealand's prehistory. Glob Change Biol 18:1609-21.

Phillips CJ, Watson AJ. 1994. Structural tree root research in New Zealand Lincoln. New Zealand: Manaaki Whenua Press.

Phillips OL, Aragao L, Lewis SL, Fisher JB, Lloyd J, LopezGonzalez G, Malhi Y, Monteagudo A, Peacock J, Quesada CA, van der Heijden G, Almeida S, Amaral I, Arroyo L, Aymard G, Baker TR, Banki O, Blanc L, Bonal D, Brando P, Chave J, de Oliveira ACA, Cardozo ND, Czimczik CI, Feldpausch TR, Freitas MA, Gloor E, Higuchi N, Jimenez E, Lloyd G, Meir P, Mendoza C, Morel A, Neill DA, Nepstad D, Patino S, Penuela MC, Prieto A, Ramirez F, Schwarz M, Silva J, Silveira M, Thomas AS, ter Steege H, Stropp J, Vasquez R, Zelazowski P, Davila EA, Andelman S, Andrade A, Chao KJ, Erwin T, Di Fiore A, Honorio E, Keeling H, Killeen TJ, Laurance WF, Cruz AP, Pitman NCA, Vargas PN, Ramirez-Angulo H, Rudas A, Salamao R, Silva N, Terborgh J, Torres-Lezama A. 2009. Drought sensitivity of the Amazon rainforest. Science 323:1344-7.

Poorter L, van der Sande MT, Thompson J, Arets EJMM, Alarcón A, Álvarez-Sánchez J, Ascarrunz N, Balvanera P, BarajasGuzmán G, Boit A, Bongers F, Carvalho FA, Casanoves F, Cornejo-Tenorio G, Costa FRC, de Castilho CV, Duivenvoorden JF, Dutrieux LP, Enquist BJ, Fernández-Méndez F, Finegan B, Gormley LHL, Healey JR, Hoosbeek MR, IbarraManríquez G, Junqueira AB, Levis C, Licona JC, Lisboa LS, Magnusson WE, Martínez-Ramos M, Martínez-Yrizar A, Martorano LG, Maskell LC, Mazzei L, Meave JA, Mora F, Muñoz R, Nytch C, Pansonato MP, Parr TW, Paz H, PérezGarcía EA, Rentería LY, Rodríguez-Velazquez J, Rozendaal DMA, Ruschel AR, Sakschewski B, Salgado-Negret B, Schietti J, Simões M, Sinclair FL, Souza PF, Souza FC, Stropp J, ter Steege H, Swenson NG, Thonicke K, Toledo M, Uriarte M, van der Hout P, Walker P, Zamora N, Peña-Claros M. 2015. Diversity enhances carbon storage in tropical forests. Glob Ecol Biogeogr 24:1314-28.

Poorter L, Bongers F, Aide TM, Almeyda Zambrano AM, Balvanera P, Becknell JM, Boukili V, Brancalion PHS, Broadbent EN, Chazdon RL, Craven D, de Almeida-Cortez JS, Cabral GAL, de Jong BHJ, Denslow JS, Dent DH, DeWalt SJ, Dupuy JM, Durán SM, Espírito-Santo MM, Fandino MC, César RG, Hall JS, Hernandez-Stefanoni JL, Jakovac CC, Junqueira AB, Kennard D, Letcher SG, Licona J-C, Lohbeck M, Marín-Spiotta E, Martínez-Ramos M, Massoca P, Meave JA, Mesquita R, Mora F, Muñoz R, Muscarella R, Nunes YRF, Ochoa-Gaona S, de Oliveira AA, Orihuela-Belmonte E, Peña-Claros M, PérezGarcía EA, Piotto D, Powers JS, Rodríguez-Velázquez J, Romero-Pérez IE, Ruíz J, Saldarriaga JG, Sanchez-Azofeifa A, Schwartz NB, Steininger MK, Swenson NG, Toledo M, Uriarte $M$, van Breugel M, van der Wal H, Veloso MDM, Vester HFM, Vicentini A, Vieira ICG, Bentos TV, Williamson GB, Rozendaal DMA. 2016. Biomass resilience of Neotropical secondary forests. Nature 530:211-14.

Powell SL, Cohen WB, Kennedy RE, Healey SP, Huang C. 2014. Observation of trends in biomass loss as a result of disturbance in the conterminous U.S.: 1986-2004. Ecosystems 17:142-57.
R Development Core Team. 2013. R: a language and environment for statistical computing. Vienna: $\mathrm{R}$ Foundation for Statistical Computing. http://www.r-project.org/ (accessed 13 July 2015).

Reichstein M, Bahn M, Ciais P, Frank D, Mahecha MD, Seneviratne SI, Zscheischler J, Beer C, Buchmann N, Frank DC, Papale D, Rammig A, Smith P, Thonicke K, van der Velde M, Vicca S, Walz A, Wattenbach M. 2013. Climate extremes and the carbon cycle. Nature 500:287-95.

Reilly MJ, Spies TA. 2015. Regional variation in stand structure and development in forests of Oregon, Washington, and inland Northern California. Ecosphere 6:1-27.

Richardson SJ, Peltzer DA, Allen RB, McGlone MS, Parfitt RL. 2004. Rapid development of phosphorus limitation in temperate rainforest along the Franz Josef soil chronosequence. Oecologia 139:267-76.

Richardson SJ, Peltzer DA, Hurst JM, Allen RB, Bellingham PJ, Carswell FE, Clinton PW, Griffiths AD, Wiser SK, Wright EF. 2009. Deadwood in New Zealand's indigenous forests. For Ecol Manag 258:2456-66.

Rosseel Y. 2012. lavaan: An R package for structural equation modeling. J Stat Softw 48:1-36.

Salk CF, Chazdon RL, Andersson KP. 2013. Detecting landscapelevel changes in tree biomass and biodiversity: methodological constraints and challenges of plot-based approaches. Can J For Res 43:799-808.

Seidl R, Schelhaas M-J, Rammer W, Verkerk PJ. 2014. Increasing forest disturbances in Europe and their impact on carbon storage. Nat Clim Change 4:806-10.

Stegen JC, Swenson NG, Enquist BJ, White EP, Phillips OL, Jørgensen PM, Weiser MD, Monteagudo Mendoza A, Núñez Vargas P. 2011. Variation in above-ground forest biomass across broad climatic gradients. Glob Ecol Biogeogr 20:744-54.

Stephenson NL, Das AJ, Condit R, Russo SE, Baker PJ, Beckman NG, Coomes DA, Lines ER, Morris WK, Ruger N, Alvarez E, Blundo C, Bunyavejchewin S, Chuyong G, Davies SJ, Duque A, Ewango CN, Flores O, Franklin JF, Grau HR, Hao Z, Harmon ME, Hubbell SP, Kenfack D, Lin Y, Makana JR, Malizia A, Malizia LR, Pabst RJ, Pongpattananurak N, Su SH, Sun IF, Tan S, Thomas D, van Mantgem PJ, Wang X, Wiser SK, Zavala MA. 2014. Rate of tree carbon accumulation increases continuously with tree size. Nature 507:90-3.

Vanderwel MC, Coomes DA, Purves DW. 2013. Quantifying variation in forest disturbance, and its effects on aboveground biomass dynamics, across the eastern United States. Glob Change Biol 19:1504-17.

Wardle P. 1973. New Guinea our tropical counterpart. Tuatara 20:114-24.

Wilmshurst JM, Anderson AJ, Higham TFG, Worthy TH. 2008. Dating the late prehistoric dispersal of Polynesians to New Zealand using the commensal Pacific rat. Proc Natl Acad Sci USA 105:7676-80.

Wiser S, Bellingham PJ, Burrows LE. 2001. Managing biodiversity information: development of New Zealand's National Vegetation Survey databank. New Zealand Journal of Ecology 25:1-17.

Wiser SK, Hurst JM, Wright EF, Allen RB. 2011. New Zealand's forest and shrubland communities: a quantitative classification based on a nationally representative plot network. Appl Veg Sci 14:506-23. 